\title{
Analysis of the Different Education Policy Reforms in Uganda (1922 - 2000)
}

\author{
Kamya Bazilio \\ PhD (c), Makerere University, Kampala,Uganda, bazilio.kamya@gmail.com
}

\begin{abstract}
Since the colonial era, Uganda has instituted several commissions of inquiry aimed at reforming the education sector. Despite these commissions, the sector still faces multiple challenges ranging from financing, poorly trained teachers, high level of teacher and student absenteeism, inadequate learning materials and large class sizes. The paper argues that much as policy reforms on primary education development that were made during the colonial times were criticized because colonial education was seen as alien, Ugandanisation of education after independence and the reforms by the successive governments did not change the sector so much. As a result, it has failed to embrace the virtues of quality, equity and efficiency yet the successive policy reform commissions have among other things been tasked to ensure that the trio is achieved. The paper is guided by both the Public value management theory and the Human capital theory. The findings of the study will inform the government about the challenges of primary education in Uganda and what went wrong with the successive policy reforms with a view to rectifying the anomalies in the future policy reforms.
\end{abstract}

KEYWORDS: policy reforms, public value theory, human capital theory, universal primary education

\section{Introduction}

For any country to pride in a strong economy, education is key and it's also a preliquisite for social and economic growth (Ozturk 2001). Formal education in Uganda dates as far back as the 1880s and was initially provided by the Christian missionaries (Syngellakis \& Arudo 2006). During the period 1924 and 1962, several commissions were set up by the then colonial government to review the education policies in Uganda and make recommendations (Ojijo 2012). By independence time (1962), Uganda's education system was not yet clearly defined until the establishment of the 1964 education Act which was formulated by Professor Edgar Castle's 1963 education commission report (Sekamwa 2000). From the report, government was to take over all the schools and this gave birth to the public school management system. Unfortunately, Uganda experienced a civil war in the 1970s and this didn't give room for the implementation of the policy (Syngellakis \& Arudo 2006).

When the new government, the National Resistance Movement (NRM) captured power in 1986, the first task in the education sector was to rehabilitate and reconstruct the education system and facilities (Ojijo 2015). The new government instituted the Prof. Senteza Kajubi Commission in 1987 that produced the Education Policy Review Commission (EPRC). In 1992, the EPRC gave birth to the government white paper on education (GWPE) whose major aim was to eradicate illiteracy and equip the individual with basic skills and knowledge to exploit the environment for self -development as well as national development for better nutrition, family life and the capability for continued learning.

\section{Theoretical framework}

The paper is guided by two theories: the Public Value Management theory and Human Capital Theory.

The Public value management theory (PVM): This was espoused by Moore in 1995 as an alternative approach to "New Public Management". The theory is centred on the needs of the public as citizens as well as consumers, the creation of value rather than achieving targets (Turell 2017). Public value is more than the aggregation of individual needs with deliberation as to what constitutes public value at its core (ibid). According to Coats and Passmore (2008), the theory explores how public organizations are operationalizing the principles of public value. The two authors further state that the theory equally focuses on the role of public engagement by amplifying the idea that public 
services are different from private competitive markets. Public value, according to the theory, therefore, is designed to get public managers to think about what is most valuable in the service that they run, and to consider how effective, management can make the service the best it can be (Coats \& Passmore 2008).

Human Capital Theory. The theory assumes that formal education is highly instrumental and even necessary to improve the production capacity of a population (Almendarez 2010). Also, it assumes that an educated population is a productive population (ibid). Schultz argued that population quality and knowledge constitute the principal determinants of the future welfare of mankind (Schultz, 1961). Human capital therefore suggests that individuals and society derive economic benefits from investment in people (Scott 1996). The investment feature of this suggestion significantly differentiates human capital expenditure from consumptive expenditure (Vaizey 1962 in Scott, 1996). On the other hand, Pascharopoulos (1985) states that education is widely regarded as the route to economic prosperity, the key to scientific and technological advancement, the means to combat unemployment, the foundation of social equity and the spread of political socialization and cultural vitality. The theory thus emphasizes that education increases the productivity and efficiency of workers.

\section{Methodology}

The paper adopts a historical design where history is used to understand the past and to untie the present in light of past events and developments. In this study, documents such as the Government White Paper (1992), the primary school curriculum, and policy reports were reviewed to generate secondary data.

Analysis of the different Education Policy Reforms in Colonial and Post-Colonial Era in Uganda (1894 - 1990) was also done.

\section{The pre-independence period}

In the 1920s and 30s, education in Uganda was available to a small group of people, and as Syngellakis \& Arudo (2006) state, these were mainly children of the aristocracy, clergy and tribal chiefs. However, as time went by, the government's role in education was expanded to include more people into the system though not everybody could access and succeed in it (Kakuru 2003). As a solution to this problem, several commissions were formed by the then government to look at the education system in Uganda.

\section{The Phelps Stokes Commission, 1924-25}

The Phelps-Stokes Commission visited Uganda towards the end of 1924 and stayed in the country for a short time at the beginning of 1925 (Ssekamwa 2000). On the invitation of the British government, the commission was to examine the state of education for Africans in Kenya, Tanzania and Uganda (ibid). The commission established that the education offered in Uganda was too literally, the activities in the schools were not related to community needs of the people and among the essential components missing in the curriculum were for instance agriculture, health science, hygiene and care of children by women (Ochieng \& Waiswa 2019).

In Uganda, the Phelps-Stokes Commission recommended that the colonial administration should participate fully in the educational activities of the country (Ssekamwa 2000) and should not leave those activities to the missionaries who had started them during the last quarter of the 19th Century. The commission also recommended the teaching of technology and handiwork, geography and handiwork, geography, science, history and music. This paved way for the government to take over the control of the education system in the country changing its development completely (Okello 2014:19-20 in Ochieng \& Waiswa 2019). According to Ssekamwa (2000), the colonial government in Uganda accepted the recommendations of the Phelps-Stokes Commission, which led 
to the establishment of the department of education in 1925 on Makerere hill. The colonial government used this department to direct and finance the educational system in Uganda (ibid). Importantly, the Commission emphasized that the government of a country was duty bound to take top responsibility for the education of the children of that country. Before 1925, the colonial government in Uganda had left the duty of education to the missionaries. It was only giving them some money on request to assist them, but without being committed to financing fully the education system and to the direction and supervision of education in the country (Ssekamwa 2000).

\section{The de La Warr Commission, 1937}

The commission was chaired by De la war (Uganda's governor between 1935-1940). Its work was to examine the state of higher education in East Africa (Ssekamwa 2000). The commission recommended that Makerere University which was established in 1922 be remodelled as a regional institute serving the British East African territories (New Vision 17th July 2012).

According to Ssekamwa (2000), the recommendations of de la war commission saw Makerere University turned into a University college in 1949 and began to offer degree courses from 1950. What this meant was that secondary schools in the East and Central African region had to be developed to feed Makerere College. As such, the Commission affected the quality of secondary schools as they had to be put on some standard to produce candidates for joining Makerere College (Ssekamwa 2000).

\section{The Thomas Education Committee of 1940}

The committee was appointed to review the education system in Uganda since 1925 (Ssekamwa 1997). Specifically, the committee was requested to examine the issue of starting non-denominational schools under the government (ibid). Among the many recommendations, two important ones deserve mention: First, it recommended the system of boards of governors for secondary schools, teacher training colleges and technical schools. Secondly, the committee recommended the financing of primary schools to be undertaken by local governments (Ssekamwa 1997). Although the committee emphasized the administration of education along religious lines (which already existed), it refused the building of nondenominational schools under the government (Ssekamwa 1997).

\section{The Post-Independence Period}

The 1963 Castle Commission

Uganda government set up the Castle commission in 1963 with the following aims: (i) to examine, in light of the recommendations of the International Bank Survey missions report, Uganda's financial position and future manpower requirements, the content and structure of education. (ii) Identify mechanisms for improving and adapting education to the needs of the country (Ssekamwa 1997).

The commission recommended large scale expansion of post primary education as a means towards training of high level manpower to manage newly gained independence (Oketch \& Rolleston, 2007). Also among its recommendations was the expansion of girls' education, emphasis on secondary education and advocacy for increased parental contribution to education (Tumushabe et al. 1999).

\section{The 1977 Education Policy Review Commission}

In 1977, the government appointed a commission to review existing policies since the Castle commission of 15 years earlier. The new commission confirmed the proposal of the $3^{\text {rd }}$ Five-year Development Plan (1972-76) to introduce Universal Primary Education by the year 2000. To make this a reality, the following were to be implemented: A) intakes in Primary one (i) were to be increased, (ii) free universal primary education in age group 6-10 was to be achieved by 1990 and (iii) by 1990, after largely achieving free universal primary education for classes P1 to P5, there would be an expansion so that upper primary would attain universal enrolment in classes up to P7. While these seemed good 
recommendations to bolster universal access to primary education, the report of the commission was never considered by government and was not published for wider circulation due to the 1979 liberation war between Uganda and Tanzania (Ssekamwa 2000). The major constraint to achieving Universal Primary Education was the negative political climate that culminated into the 1978/9 war which in turn led to massive destruction of educational infrastructure and deterioration of facilities (MoES 1989). Another period of insurgency ensued and government was preoccupied with the guerrilla war between 1981 and 1985.

\section{The 1989 Education Policy Review Commission}

The New government (National Resistance Movement) appointed the Education Policy Review Commission under Professor Senteza Kajubi in 1987 and gave the commission the following terms: (i) recommending policies at all levels i.e. primary, secondary and tertiary, (ii) making policies about aims and objectives of education, (iii) coming up with policies about the structure of the education system and (iv) integrating the role of the private sector in education.

Professor Kajubi led a team of high profile people to do the job for which he was appointed and after thorough consultations with all stakeholders, the commission came up with, the following recommendations: (i) Universal Primary Education (UPE) for children of age group 6-10 should be achieved by the year 2000, (ii) by the year 2000, it should be ensured that children enter school at the right age of 6 years and that (iii) Universalization of primary education for children aged 6-13 should be achieved soon after 2000 and not later than 2010. The spirit of the framers of the Education Review Policy Commission Report was that the goal for UPE should be that all children aged 6-10 years are enrolled and that they complete at least five years of schooling in order to be equipped with essential literacy, numeracy and other skills envisaged in the package of basic education (Ssekamwa 2000).

Once the above was achieved, the next target was achieving full universalization of primary education covering all children of the age group 6-13 corresponding to grades 1 to 8 (MoES 1989). The Report of the education Policy Review Commission was debated by government which consolidated the latter into the Government White Paper (MoES 1989). However, the Association for the Development of African Education, DAE (1995) states that the commission did not fully exploit the supportive conditions of post-war period to consult with citizens and key education stakeholders at all levels of society and in all regions of the country. Its consultations were only held in urban centers and therefore the rural communities were never consulted. In other words, those who drafted the commission's terms of reference and the top education officials who sanctioned and issued them did not encourage the commission to maximize stakeholder participation (DAE 1995).

\section{The 1992 Government White Paper}

In response to the Education Policy Review Commission Report, government appointed the White Paper committee to examine the report and identify recommendations which would be acceptable and feasible to implement and make amendments where necessary. The White Paper Committee largely accepted the recommendations of the Education Policy Review Commission with a slight modification. It shifted the target of achieving UPE from 2000 as per Education Policy Review Commission to "as soon as possible" but not later than 2001/2 (MoES 1992) according to the White Paper. In this regard, the white paper recommended the introduction of free compulsory primary education starting in 1992/93 in which case fees would be eliminated in phases through the following manner: 1992/93: abolishing fees for Primary four (P4) in all schools in Uganda. 1993/94: abolishing fees for P5 in all schools and continuing to add one class upwards per year until P8 would be reached in 1996/7.1997/8: abolishing fees for P3 in all schools and continuing to add one class downwards per year until the whole primary cycle would be covered (P1-P8) in 1999/2000. Making school attendance compulsory for every class in which free education was introduced and all basic education, free and compulsory by the year 2000/1. 
It should be noted that there was considerable delay in finalizing the draft White Paper and hence recommendations to achieve the envisaged targets could not easily be implemented. While the Report of the Castle Commission was the main policy document in the area of education in the first three decades of independence, the Education Policy Review Commission report and by implication, the Government White Paper has remained the main education Policy document in the area of education to date.

\section{The advent of Universal Primary and Secondary education}

While plans for UPE had been finalized by 1992 as per Government White Paper, the implementation came to pass in 1997 after Museveni (the President of Uganda) announced that free education for 4 children per family would commence in January 1997 amidst the 1996 presidential election campaigns. The key objectives of UPE as summarized by Hedger, Williamson, Muzoora, \& Stroh (2010) were:

i) Making basic education accessible to the learners and relevant to their needs as well as meeting national goals;

ii) Making education equitable in order to eliminate disparities and inequalities; • establishing, providing and maintaining quality education as the basis for promoting the necessary human resource development;

iii) Initiating a fundamental positive transformation of society in the social, economic and political fields and;

iv) Ensuring that education is affordable by the majority of Ugandans by providing, initially, the minimum necessary facilities and resources, and progressively the optimal facilities, to enable every child enter and remain in school until they complete the primary school education cycle.

While President Museveni's initiative was pragmatic and well received, it was at variance with what government had accepted in the White Paper (the phasing of UPE implementation) for not only weren't there enough teachers, instructional materials and physical facilities to accommodate the surge in enrolments, it also became a sudden financial burden to government. In addition, the definition of the family was also problematic and compounded by polygamy and single parenthood. It was later accepted that all children could enrol in school under UPE. This haphazard implementation of the UPE policy, in the context of high population growth rates and declining public resources has caused "enrolment shocks" that have led to the decline of quality in schools (Deininger 2003; Lewin 2009; Oketch \& Rolleston 2007).

As part of the implementation of the Poverty Eradication Action Plan 2005-2010 (PEAP), the Ugandan government introduced the Universal post primary education and training Policy in 2007. Through the policy that has taken on the appellation "Universal Secondary Education (USE) Policy", government was to provide free tuition to secondary school students starting with 300,000 primary school graduates in 2007.

\section{Challenges to education sector in Uganda}

Amidst the many policy reforms as shown above, Uganda's education sector still faces many challenges. Importantly, the biggest challenge facing the education sector in Uganda is financing. For instance, NPA (2019) states that education expenditure from the national budget has been on the decline or stagnant in the range of $10-12 \%$ compared to $22 \%$ in $2001 / 2$. Over the last 20 years, UPE capitation grant has been stagnated between UGX 5,737 and UGX 10,000 far below the estimated threshold of UGX 59,000 (NPA 2019). NPA (2018) states that the share of public expenditure allocated to education has significantly declined since 2001/02 in line with changing government priorities and the high population growth rate. Compared to countries in the East African region, Uganda has the lowest education spending as proportion of GDP (ibid).

Further, majority of primary schools have limited capacity to provide the quality of education required. For instance, school management in majority schools are clueless and apathetic; majority of teachers are pedagogically weak; and teacher professionalism is on a steady decline (NPA 2019) 
Aguti and Fraser (2005) state that the issue of quality is still unresolved in teacher education. True, through these programmes a number of trained teachers have been added to the system; but the enormous increase in primary school enrolments and the growing numbers of secondary schools in the country still exceed these efforts by far. Much more therefore needs to be done, otherwise schools will continue to be filled with untrained teachers and this could have an adverse effect on the quality of primary school education.

The automatic promotion policy in UPE schools has caused more problems than it has solved. Although the policy was meant to ensure a smooth flow in the UPE system and enable a reduction in repetition rates (NPA 2018), it has greatly undermined the quality and skills acquired by children as well as encouraging both pupils and parents to wrongly assume that what matters in order to gain promotion is to do exams an $\mathrm{d}$ not necessary to pass (ibid).

The quality of teachers has too been a big challenge. According to Overseas Development Institute (2005), in 2003, there were 145,703 primary schoolteachers, of whom $54,069(37 \%)$ had no formal teacher training. Further, 7,960 had just a teaching certificate, obtained after training on completion of primary education (ibid).

Corruption and embezzlement of funds has been another major challenge. The media in Uganda for the last decade has been awash with reports on gross embezzlement of UPE funds. To cite a few, Semakula and Nsubuga (2010) reported that the headmaster of Kiyagi Primary School in Najjembe sub-county embezzled Universal Primary Education (UPE) funds amounting to 800,000 UGX meant to lay a foundation for two block classrooms.

Tiberondwa (1999) summarizes the challenges of UPE in the first two years of implementation thus: (i) high pupil teacher-ratios (100:1) while many qualified grade 3 , grade 5 and graduate teachers were not employed; (ii) increased enrolments at primary that were not catered for at post primary level; (iii) big classes, smaller rooms and few teachers; (iv) teachers had lost income through the abolition of PTA fees; (v) shortage of latrines at schools to cater for increased numbers; (vi) shortage of water supplies in schools; (vii) increased wage bill on the part of government and (viii) expected fall in quality due to high pupil teacher ratios.

\section{Conclusion}

From colonial times up to date, despite the numerous efforts to rehabilitate and reconstruct the education system and facilities aimed at improving the inequalities and inefficiency through several policy documents implemented through Ministry of Education, Sports and Technology, primary education has remained poor. Much as policy reforms on education development that were made during the colonial times were criticized because colonial education was seen as alien, Ugandanisation of education after independence and the reforms by the successive governments did not change the sector so much. As a result, it has failed to embrace the virtues of quality, equity and efficiency yet the successive policy reform commissions have among other things been tasked to ensure that the trio is achieved.

\section{References}

Almendarez L. 2010 "Human capital theory: Implications for Educational Development." Available on https:/www.open.uwi.edu/sites/default/files/bnccde/belize/conference/papers2010/almendarez.html. Retrieved $27^{\text {th }}$ October 2019.

Association for Development of African Education (DAE) 1995. Formulating Education policy: Lessons and experiences from Sub-Saharan Africa. Six case studies and reflections from the DAE Biennial Meetings, Tours, France.

Aguti, J.N. \& Fraser J.W. 2005. "The challenges of universal primary education in Uganda through distance education programmes." Africa Education Review 2(1): 91-108. Doi:10.1080/18146620508566293.

Coats, D. \& Passmore E. 2008. Public value: The next steps in public service reform. http://citeseerx.ist.psu.edu/viewdoc/download?doi=10.1.1.549.8241\&rep=rep1\&type=pdf

Deininger, K. 2003. "Does cost of schooling affect enrollment by the poor? Universal primary education in Uganda." Economics of Education Review 22(3): 291-305. Doi: 10.1016/S02727757 (02)00053-5.

Govender, P. and G. Steven. 2004. "Nepad Policy Focus Series Back to the Blackboard Looking Beyond Universal Primary Education in Africa." The South African Institute of International Affairs. 
Government of Uganda. 1995. The Constitution of the Republic of Uganda. Kampala, Uganda.

Government of Uganda. 2008. The Education Act, 2008. UPPC, Entebbe.

Harbison, R. \& Hanushek, E. 1992. Education Performance of the Poor: Lessons from North east Brazil. New York: Oxford University Press.

Kakuru, M.D. 2003. Gender Sensitive Education Policy and Practice, Uganda case study. Kampala: Makerere University, Department of Sociology.

Lewin, K., \& Akyeampong, K. 2009. "Education in sub-Saharan Africa: researching access, transitions and equity." Comparative Education 45(2): 143-150. Doi: 10.1080/03050060902920492.

MoES. 1989. Report of the Education Policy Review Commission. Kampala, Uganda: Ministry of Education and Sports.

MoES. 2001. The Development of Education in Uganda in the last 10 Years. Geneva: Ministry of Education and Sports.

National Planning Authority, NPA. 2018. Comprehensive Evaluation of Universal Primary Education (UPE) Policy. Synthesis Report.

National Planning Authority, NPA. 2018. Comprehensive Evaluation policy of the Universal Primary Education (UPE) Policy. Financing and costing of UPE, Thematic Report 5.

New vision. 2017. The Castle, Kajubi commissions set the basis for Uganda's education, $17^{\text {th }}$ July 2017, available on https://www.newvision.co.ug/new_vision/news/1304099/castle-kajubi-commissions-set-basis-ugandaeducation, Retrieved $1^{\text {st }}$ November 2019.

Ochieng A.S and Waiswa C.D 2019. "Pastoral Education. The missing Link in Uganda Education system." Educational Research and Reviews 14(7): 240-253.

Ojuji, P. 2014. "Review of education policy in Uganda." Working paper submitted to Uganda National Curriculum Development Centre.

Okello B 2014. The History of Technical Education in Uganda, Fountain Publishers Kampala in Ochieng A.S and Waiswa C.D 2019. Pastoral Education. The missing Link in Uganda Education system. Educational Research and Reviews 14(7): 240-253.

Oketch, M., \& Rolleston, C. 2007. "Policies on free Primary and secondary Education in East Africa, Retrospect and prospect." Review of Research in Education 31: 131-158.

Overseas Development Institute 2005. Universal primary education, Uganda. Policy Brief 10. Available on https://www.odi.org/sites/odi.org.uk/files/odi-assets/publications-opinion-files/4072.pdf

Ozturk, Iihan 2001. "The role of education in Economic development. A theoretical perspective." Journal of Rural Development and Administration. 33(1) 39-47.

Psacharopoulos, G. 1985. "Returns to Education. A further international update and implications." Journal of Human Resources, 20 (4): 583-604

Pilon, M., \& Wayack-Pambè, M. 2002. Evolution de l'enseignement secondaire au Burkina Faso de 1960 à 1999 (Etudes ET Documents No. 8). Ouagadougou: UERD.

National Planning Authority 2019. Comprehensive Evaluation of the Universal Primary education (UPE) policy: Synthesis Summary Report. A paper presented by the executive Director, Kampala.

Republic of Uganda. 2018. Comprehensive Evaluation of the Universal primary Education (UPE) policy. Financing and costing of UPE. Thematic report 5. National Planning Authority.

Republic of Uganda. 1992. Government White paper on the Education policy Review Commission Report on Education for National Integration and Development. Kampala: Republic of Uganda.

Scott, R.S. 1996. "Human Capital theory: Foundations of a field inquiry." Review of Educational Research 66(3): 341359.

Ssekamwa, J.C. 1971. Readings in the Development of Education in East Africa. Kampala: Makerere University Printery.

Ssekamwa, J.C. 1985. "Education policies in Uganda and influences on them 1925-1960." Ph.D. Thesis, Makerere University.

Ssekamwa, J. C. 1997. History and Development of Education in Uganda. Kampala: Fountain Publishers.

Ssekamwa, J.C. 2000. History and development of Education in Uganda, second edition. Kampala: Fountain Publishers.

Syngellakis, K. \& Arudo, E. 2006. Uganda: Education Sector Policy Overview Paper. UK: ENABLE-Energy for Water, Health, Education.

Tiberondwa, A. K. 1999. Missionary Teachers as Agents of Colonialism in Uganda (2nd ed.). Kampala: Fountain Publishers.

Tumushabe, J., Barasa C., Muhanguzi F. \& Otim-Nape. 1999. Gender and primary schooling in Uganda. FAWE.

Turell, Alan. 2017. Public value management theory: Applying public value management theory to procurement. CIPS.

Vaizey, J. 1962. "The economics of education." London. Faber and Faber in Scott, R.S. (1996). Human Capital theory: Foundations of a field inquiry. Review of Educational Research 66 (3): 341-359.

Williamson, Muzoora, \& Stroh. 2010. Sector Budget Support in Practice Case Study Education Sector in Uganda, Final Draft February 2010. 